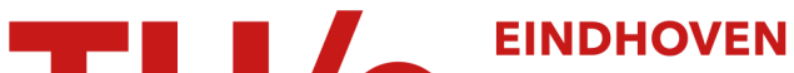 \\ UNIVERSITY OF \\ TECHNOLOGY
}

\section{Electrochemical behaviour of iodide at a rotating platinum disk electrode in methanol}

Citation for published version (APA):

Verhoef, J. C., \& Barendrecht, E. (1978). Electrochemical behaviour of iodide at a rotating platinum disk electrode in methanol. Electrochimica Acta, 23(5), 433-438. https://doi.org/10.1016/0013-4686(78)87042-X

DOI:

10.1016/0013-4686(78)87042-X

Document status and date:

Published: 01/01/1978

\section{Document Version:}

Publisher's PDF, also known as Version of Record (includes final page, issue and volume numbers)

\section{Please check the document version of this publication:}

- A submitted manuscript is the version of the article upon submission and before peer-review. There can be important differences between the submitted version and the official published version of record. People interested in the research are advised to contact the author for the final version of the publication, or visit the $\mathrm{DOI}$ to the publisher's website.

- The final author version and the galley proof are versions of the publication after peer review.

- The final published version features the final layout of the paper including the volume, issue and page numbers.

Link to publication

\section{General rights}

Copyright and moral rights for the publications made accessible in the public portal are retained by the authors and/or other copyright owners and it is a condition of accessing publications that users recognise and abide by the legal requirements associated with these rights.

- Users may download and print one copy of any publication from the public portal for the purpose of private study or research.

- You may not further distribute the material or use it for any profit-making activity or commercial gain

- You may freely distribute the URL identifying the publication in the public portal.

If the publication is distributed under the terms of Article 25fa of the Dutch Copyright Act, indicated by the "Taverne" license above, please follow below link for the End User Agreement:

www.tue.nl/taverne

Take down policy

If you believe that this document breaches copyright please contact us at:

openaccess@tue.nl

providing details and we will investigate your claim. 


\title{
ELECTROCHEMICAL BEHAVIOUR OF IODIDE AT A ROTATING PLATINUM DISK ELECTRODE IN METHANOL
}

\author{
J. C. VERHOEF* \\ Laboratory of Analytical Chemistry, Free University, de Boelelaan 1083, Amsterdam \\ and \\ E. BARENDRECHT \\ Labaratory of Electrochemistry, University of Technology, \\ P.O. Box 513, Eindhoven, The Netherlands
}

(Received 16 May 1977)

\begin{abstract}
The oxidation of iodide at a rotating platinum disk electrode in methanol has been studied. At low concentrations only one oxidation wave is seen, but at higher concentrations two steps are discerned. This is in accordance with the theory, assuming that the equilibrium between iodide, triiodide and iodine is reached fast and the oxidation of iodide to iodine occurs reversibly.

Only in approximately neutral and moderately alkaline solutions jodine can be oxidized to iodonium methoxide. The oxidation occurs irreversibly. Neutralization titrations confirm the formation of iodonium methoxide.

The diffusion coefficients of the iodine species and the stability constant of the tribodide ion were determined.
\end{abstract}

\section{INTRODUCTION}

For several reasons the voltammetry of jodide in various solvents is of interest. Though the behaviour of iodide in aqueous solutions has been studied extensively[1], just as in many organic solvents, as acetic acid[2], acetonitrile[3], dimethylformamide [4], dimethylsulfoxide[5], nitromethane[6] and pyridine[7], remarkably little has been published on the voltammetry of iodide in methanol. In the context of research on the coulometric Karl-Fischer titration reaction, which is very often performed in methanol, we have investigated the electrochemical behaviour of iodide in this solvent. We have confined ourselves to iodide species with oxidation numbers $-1,-1 / 3,0$ and +1 , since higher oxidation numbers than +1 are not of importance in the context of our investigations on the Karl-Fischer titration.

Oxidation of iodide to iodine

In dilute methanolic solutions up to $\mathrm{ca} 1 \mathrm{mM}$, iodide shows one oxidation wave to iodine, while in more concentrated solutions it is clearly oxidized in two steps, via the formation of triiodide:

$$
\begin{aligned}
2 \mathrm{I}^{-} & \rightleftharpoons \mathrm{I}_{2}+2 e^{-} \\
\mathrm{I}_{2}+\mathrm{I}^{-} & \rightleftharpoons \mathrm{I}_{3}^{-} \\
2 \mathrm{I}_{3}^{-} & \rightleftharpoons 3 \mathrm{I}_{2}+2 e^{-}
\end{aligned}
$$

Guidelli and Piccardi[8] calculated the theoretical voltamograms of iodide--iodine solutions as a function of the total concentration of the various iodine species, $C$, and the stability constant of the triiodide ion, $K_{s}$, assuming that the following assumptions are valid:

(1) The electron transfer is rapid, so that there is only diffusion overpotential;

(2) The diffusion coefficients of the various iodine species are equal;

(3) Triiodide is at any time in equilibrium with iodide and iodine;

* Present address: Central laboratory DSM, department MCO, PO Box 10, Geleen, the Netherlands.
(4) Concentrations may be used instead of activities. They showed that

$$
\begin{array}{r}
\theta=\frac{4 K\left[4 C+P-\sqrt{ }\left(P^{2}+16 Q C K\right)\right]}{\left(3 P^{2}+12 Q C K-4 P K\right) \cdot \sqrt{ }\left(P^{2}+16 Q C K\right)} \\
+4 Q C K(8 K-9 P)+P^{2}(4 K-3 P)
\end{array}
$$

where $\theta$ is given by Nernst's law :

$$
\begin{aligned}
& \theta=\exp \left\{\frac{2 F}{R T}\left(E-E_{\mathrm{l}_{2,}-}^{0}\right)\right\}=c_{\mathrm{l}_{2}}^{0}\left(c_{1-}^{0}\right)^{2}, \\
& Q=\left(i-i_{a, d}\right) /\left(i_{c, d}-i_{a, d}\right)
\end{aligned}
$$

$i_{a, d}$ and $i_{c, d}$ are, respectively, the anodic and cathodic diffusion currents in the voltamogram,

$$
\begin{aligned}
K & =1 / K_{s}=c_{\mathbf{r}^{-}} \cdot c_{\mathrm{I}_{2}} / c_{\mathrm{l}_{\overline{3}}}, \\
P & =2 K+C-3 C Q
\end{aligned}
$$

and

$$
C=c_{1^{-}}+2 c_{1_{2}}+3 c_{1_{3}} .
$$

It can be shown that, if $C$ and $K$, are large, the voltamogram can be considered to be composed of the independent waves of the iodide-triiodide couple and the triiodide-iodine couple. So:

$$
\begin{aligned}
& \theta_{1}=\frac{4(1-Q)}{C^{2}(3 Q-1)^{3}} \\
& =\exp \left\{\frac{2 F}{R T}\left(E-E_{\mathrm{I}_{3} / I^{-}}^{0}\right)\right\}=c_{\mathrm{T}_{3} /\left(c_{\mathrm{I}_{3}^{3}}^{0}\right)^{3}}^{0} \\
& \theta_{2}=\frac{C(1-3 Q)^{3}}{8 Q^{2}} \\
& =\exp \left\{\frac{2 F}{R T}\left(E-E_{1_{2} / I_{3}}^{0}\right)\right\}=\left(c_{1_{2}}^{0}\right)^{3} /\left(c_{T_{3}}^{0}\right)^{2}
\end{aligned}
$$

In the voltamogram of the oxidation of iodide to iodine, the potential where the current is $1 / 3$ of the diffusion current $(Q=2 / 3)$ and the potential where the 
current is $5 / 6$ of the diffusion current $(Q=1 / 6)$ correspond with the halfwave potentials of the first and the second step, respectively. They are not constant, but depend on the total concentration:

$$
\begin{gathered}
E_{1 / 2,1_{3} / I^{-}}=E_{1_{3} / I^{-}}^{0}+\frac{R T}{2 F} \ln \frac{4}{3 C^{2}} \\
E_{1 / 2, I_{2} I_{3}^{-}}=E_{l_{2} / I_{3}}^{0}+\frac{R T}{2 F} \ln \frac{9 C}{16}
\end{gathered}
$$

As

$$
\Delta E^{0}=E_{1_{3} I^{-}}^{0}-E_{1_{5} / I^{-}}^{0}=\frac{3 R T}{2 F} \ln K_{s^{\prime}}
$$

the stability constant of the triiodide ion can be calculated from the difference of the halfwave potentials :

$$
\Delta E_{1 / 2}=E_{1 / 2,1_{2} / I_{j}}-E_{1 / 2,1_{3}^{3} I^{-}}=\frac{3 R T}{2 \mathrm{~F}} \ln \left(3 / 4 K_{s} C\right)
$$

From (10) and (11) it appears, that for decreasing total concentrations of the iodine species, the half-wave potential of the first step increases and the half-wave potential of the second step decreases, so that at small total concentrations of the iodine species the two waves merge. Then:

$\theta=\frac{1-Q}{2 C Q^{2}}=\exp \left\{\frac{2 F}{R T}\left(E-E_{1_{2} n^{-}}^{0}\right)\right\}=c_{\mathrm{l}_{2}}^{0} /\left(c_{1^{-}}^{0}\right)^{2}$

With this equation, we find that $E_{3 / 6}-E_{1 / 3}=47.4 \mathrm{mV}$ for a voltamogram, where the oxidation from iodide to iodine is shown as a single wave. This means, that only when the difference between $E_{5 / 6}$ and $E_{1 / 3}$ is sufficiently larger than $47.4 \mathrm{mV}$, this difference can be used to calculate a $K$, value. It also follows from (14) that the half-wave potential of the single wave oxidation of iodide to iodine is concentration dependent:

$$
E_{1 / 2, \mathrm{I}_{2}, \mathrm{I}^{-}}=E_{\mathrm{l}_{2}, \mathrm{I}^{-}}^{0}+\frac{R T}{2 F} \ln \frac{1}{\mathrm{C}}
$$

\section{EXPERIMENTAL}

\section{Apparatus}

Use was made of a platinum disk electrode (dia $4 \mathrm{~mm}$ ), embedded in a Kel-F shaft and driven by a servomotor with tachogenerator. The rotation speed was variable from zero to $5000 \mathrm{rpm}$.

The cell consisted of a thermostatted main compartment of approximately $120 \mathrm{ml}$; the compartments for the platinum wire auxiliary electrode and the silversilver chloride reference electrode (in methanol, saturated with $\mathrm{KCl}$ ) were connected to the main compartment via a glass frit (P3-glass) and a Luggin capillary, respectively.

The potentiostat, a Tacussel PRT 30-01, was coupled to a UAP4 pulse unit and a UAP3 AC-unit. Recordings were made on a EPL recorder belonging to the system.

Potentiometric experiments were carried out in a thermostatted $\mathrm{H}$-shaped cell with a P4-glass frit separating the two compartments (each about $7 \mathrm{ml}$ ). The potential difference between the platinum wire electrodes in each compartment was measured with a Hewlett-Packard 34703A digital voltmeter coupled to a PAR 135 electrometer.

$\mathrm{pH}$ measurements were carried out with a Metrohm E516 pH meter and a Metrohm glass electrode.

\section{Reagents}

Methanol (Baker, analytical grade, containing no more than $0.02 \%$ water), lithium nitrate (Baker, A.R.), lithium iodide (Alfa Inorganics, anhydrous), sodium iodide (Merck, p.a.), sodium bydroxide (Baker, A.R.) and tetramethyl ammonium hydroxide (EGA, ca $3 \mathrm{M}$ solution in methanol) were used without purification.

Sodium methoxide was prepared from sodium metal and methanol; anilinium perchlorate was prepared from aniline (Merck, p.a.) and perchloric acid (Baker, A.R.) and purified by recrystallization from methanol.

Buffers were prepared with sodium acetate, sodium hydroxide or TMA hydroxide and acetic acid (pH 8.5-10.5), monochloroacetic acid (pH 7-9), dichloroacetic acid (pH 5-7.5), trichloroacetic acid (pH 2.5-5), and perchloric acid.

Aniline solutions are not stable and are used only for calibration. The buffer reagents were either Baker of Merck, analytical grade, if possible. They were also used without further purification.

\section{Procedure}

After the cell was filled with the methanolic solution of the iodine species, buffer reagents and lithium nitrate as a supporting electrolyte (to a total ionic strength of $0.5 \mathrm{M}$ ), the $\mathrm{pH}$ was, if necessary, adjusted to the desired value. The $\mathrm{pH}$ was checked after the experiments and a shift less than $0.1 \mathrm{pH}$ unit was considered as acceptable.

The glass electrode-pH meter combination was calibrated for methanolic solutions with, respectively, a $0.01 \mathrm{M} \mathrm{HClO}_{4}$ solution for $\mathrm{pH}=2.0$, a fresh anilineanilinium perchlorate solution for $\mathrm{pH}=6.0$ and a TMA acetate-acetic acid solution for $\mathrm{pH}=9.7$. The dissociation constants for anilinium and acetic acid were taken from the literature [9]. The glass electrode was kept in an aqueous $3 \mathrm{M} \mathrm{KCl}$ solution and, after rinsing with methanol, calibrated before each experiment.

The voltammetric experiments were usually performed in the pulse mode of the Tacussel polarograph, with a pulse duration of $500 \mathrm{~ms}$ and a pulse frequency of $1 \mathrm{~Hz}$. Sampling was carried out from 79 to $99 \%$ of the pulse. The pulse mode gives a much better reproducibility when solid electrodes are used. The pulse duration is so long, that during the sampling time a steady-state regime is achieved, as was always checked with a Tektronix model $5103 \mathrm{~N}$ oscilloscope, coupled to the current-voltage converter of the polarograph. The limiting currents obtained in the pulse mode therefore differed less than $1 \%$ from the limiting currents measured in the $d c$ mode.

Unless otherwise stated, all experiments were carried out at $25.0 \pm 0.3^{\circ} \mathrm{C}$.

\section{RESULTS AND DISCUSSION}

\section{Oxidation of iodide to iodine}

We determined the diffusion coefficients of the 
various iodine species from the limiting currents at a rotating disk electrode, using the improved version of the Levich equation[10]:

$$
i_{L}=\frac{0.6205 n F A v^{-1 / 6} D^{2 / 3} \omega^{1 / 2} c^{\infty}}{1+0.298 v^{-1 / 3} D^{1 / 3}+0.145 v^{-2 / 3} D^{2 / 3}}
$$

where all symbols have their usual significance. The results are shown in Table I, from which it appears that the assumption of equal coefficients is reasonably justified.

Table 1. Diffusion coefficients $\times 10^{9} \mathrm{~m}^{2} \mathrm{~s}^{-1}$ of iodine species in methanolic solutions

\begin{tabular}{lcclc}
\hline & $\mathrm{I}^{-}$ & $\mathbf{I}^{-}$ & $\mathrm{I}_{2}$ & $\mathrm{I}^{+}$ \\
\hline $\mathrm{pH}=4$ & 1.09 & 1.08 & 1.20 & 1.14 \\
$\mathrm{pH}=8.5$ & 1.11 & 1.10 & 1.17 & - \\
\hline
\end{tabular}

From the $\left(E_{5 / 6}-E_{1 / 3}\right)$-value of a voltamogram of $10 \mathrm{mM}$ iodide with $0.5 \mathrm{M} \mathrm{LiNO}$ in methanol we calculated the stability constant of the triiodide ion with (13). We found $E_{5 / 6}-E_{1 / 3}=0.182 \mathrm{~V}$, from which follows:

$$
K_{s}=c_{l_{5}} / c_{l^{-}} \cdot c_{l_{2}}=10^{4.18} \text { (at } 25^{\circ} \mathrm{C} \text { ) }
$$

Durand and Tremillon[2] prefer the potentiometric determination of $K_{s}$ because the Guidelli and Piccardi method neglects the possible intervention of various electrokinetic phenomena that could make this type of determination erroneous. If the stability constant of the triiodide ion is relatively large, it is reasonable to suppose, that in a solution of iodine and a targe excess of iodide, the former is almost completely converted into triiodide, while in a solution of a large excess of iodine over iodide, the latter is almost completely converted into triiodide. We therefore measured the potential of a platinum wire electrode us a saturated methanolic $\mathrm{Ag} / \mathrm{AgCl}$ reference electrode in a $10 \mathrm{mM} \mathrm{I}_{2}$ $+100 \mathrm{mM} \mathrm{LiI}$ solution and in a $100 \mathrm{mM} \mathrm{I}_{2}$ $+10 \mathrm{mM}$ LiI solution (both solutions were adjusted wilh lithium nitrate to ionic streng th 0.5 ). At $25.0^{\circ} \mathrm{C}$ we found, after correction for the logarithmic terms in the Nernst equation,

$$
\begin{aligned}
E_{\mathrm{l}_{3} / \mathrm{I}^{-}}^{0} & =0.210 \pm 0.002 \mathrm{~V} \\
E_{\mathrm{I}_{2} / \mathrm{I}^{5}} & =0.599+0.002 \mathrm{~V} \\
\Delta E^{0} & =0.389 \pm 0.004 \mathrm{~V}
\end{aligned}
$$

In order to eliminate as much as possible the effect of variation of the liquid junction potential, we used a Hshaped cell with a glass frit separating the two compartments. One compartment was filled with the $\mathrm{I}_{2}^{+}$excess $\mathrm{I}^{-}$solution, while the other was filled with the $\mathrm{I}^{-}+$excess $\mathrm{I}_{2}$ solution. The potential difference between the platinum electrodes in each compartment equalled, after correction for the logarithmic terms (only about $10 \mathrm{mV}$ ), the difference $\Delta E^{0}=E_{\mathrm{I} / \mathrm{I}_{3}^{-}}^{0}$ $-E_{1-1 I^{-}}^{0}$ At $25.0^{\circ} \mathrm{C}$ we found $\Delta E^{0}=0.3876$ $\pm 0.0003 \mathrm{~V}$, only slightly less than the difference of the $E^{0}$ values previously stated. From this difference we calculate with (12):

$$
\log K_{s}=4.37
$$

in reasonable agreement with the value found by the Guidelli and Piccardi method. The H-shaped cell makes it easy to perform temperature measurements; the results of them are tabulated in Table 2. A plot of $\ln K_{s}$ vs $1 / T$ gives a straight line with slope $4.85 \times 10^{3}( \pm 0.9 \%)$ from which follows $\Delta H^{0}=40.3 \pm 0.4 \mathrm{~kJ} / \mathrm{mol}$.

Table 2. Temperature dependence of $\Delta E^{0}$ and $K$,

\begin{tabular}{ccc}
\hline$T /^{\circ} \mathrm{C}$ & $\Delta E^{0} / V_{t s} \mathrm{Ag} / \mathrm{AgCl}$ & $\log K_{3}$ \\
\hline 15.0 & 0.3966 & 4.63 \\
20.0 & 0.3920 & 4.49 \\
25.0 & 0.3876 & 4.37 \\
30.0 & 0.3832 & 4.25 \\
35.0 & 0.3792 & 4.13 \\
40.0 & 0.3756 & 4.03 \\
45.0 & 0.3720 & 3.93 \\
50.0 & 0.3687 & 3.83 \\
\hline
\end{tabular}

We used a value $K=10^{4 \cdot 2}$ to calculate the voltamograms according to (4) for a $0.1,1.0$ and $10 \mathrm{mM}$ iodide solution. The agreement with the experimental voltamograms is very satisfactory (Fig. 1). This prompts the suggestion, that the electrode reaction is rapid and that the oxidation occurs reversibly. A good criterion for reversibility is, that the peak height of an ac voltamogram is proportional to the square root of the modulation frequency $[11]$ :

$$
i_{a c}=\frac{n^{2} F^{2} A c^{\infty} D^{1 / 2} \Delta E(2 \pi f)^{1 / 2}}{4 R T \cosh h^{2}(j / 2)} \sin \left(2 \pi f t+\frac{\pi}{4}\right)
$$

where $\Delta E$ is the modulation amplitude, $f$ the modulation frequency, $j$ is given by

$$
j=\frac{n F}{R T}\left(E_{\mathrm{dc}}+\Delta E \sin (2 \pi f t)-E_{1 / 2}\right)
$$

and the other symbols have their usual significance. As can be seen in Fig. 2, this criterion is met for different rotation speeds. The current is diffusion controlled and therefore proportional to the square root of the rotation speed at various potentials (Fig. 3).

\section{Oxidation of iodide to iodonium}

The oxidation of iodide to triiodide and iodine in methanol is not dependent on the pH of the solution, in contrast with the oxidation to iodonium. In Figure 4, the voltamograms are shown for the oxidation of iodide at $\mathrm{pH}=4.0$ and at $\mathrm{pH}=8.5$. In the acidic solution there is only one wave for oxidation of iodide to iodine. In the slightly alkaline solution, there are two waves of approximately equal height for the oxidation of iodide to iodine and further to iodonium. The height of the iodonium wave is $\mathrm{pH}$ dependent: down to about $\mathrm{pH}=8$, it is equal to the height of the iodine wave, but at lower $\mathrm{pH}$ values it decreases (Fig. 5).

The half-wave potential for the oxidation of iodine to iodonium is $\mathrm{pH}$ dependent and shifts to less positive values at increasing pH (Fig. 6a). The same is observed for the reduction of iodonium dipyridine nitrate, which is reasonably stable in acidic solutions and can be kept for a short time. However, the half-wave potentials for the oxidation of iodine to iodonium and for the reduction of iodonium to iodine do not coincide at a given $\mathrm{pH}$ value (Fig. 6b). 


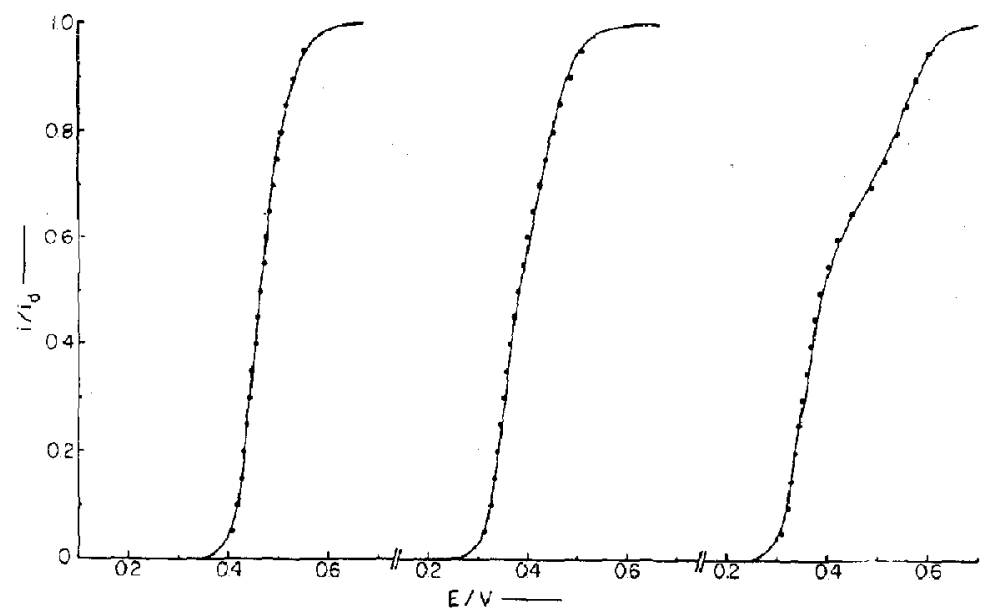

Fig. 1. Comparison of the experimental voltamograms (solid lines) with the theoretical voltamograms (dots) for $0.1,1.0$ and $10 \mathrm{mM}$ solutions of iodide in methanol; $\omega=25 \mathrm{rps}$.

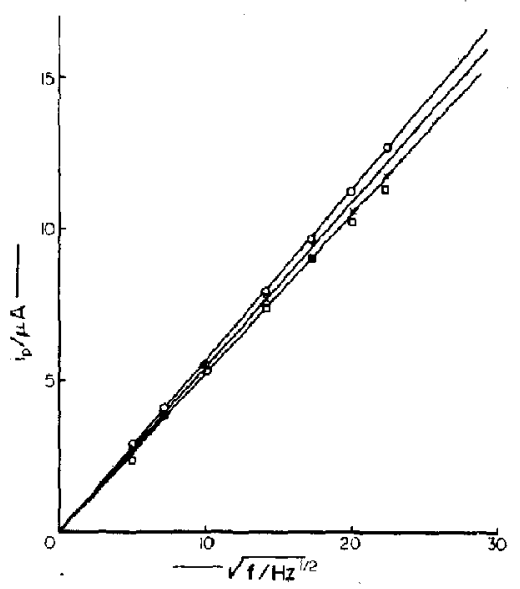

Fig. 2. Peak current of the $a c$ voltamograms as function of the square root of the modulation frequency, $f . c_{\mathrm{t}^{-}}=1 \mathrm{mM}$, $\Delta E=10 \mathrm{mV}, \omega=(O) 16 \mathrm{rps},(x) 36 \mathrm{rps}$, (口) $64 \mathrm{rps}$.

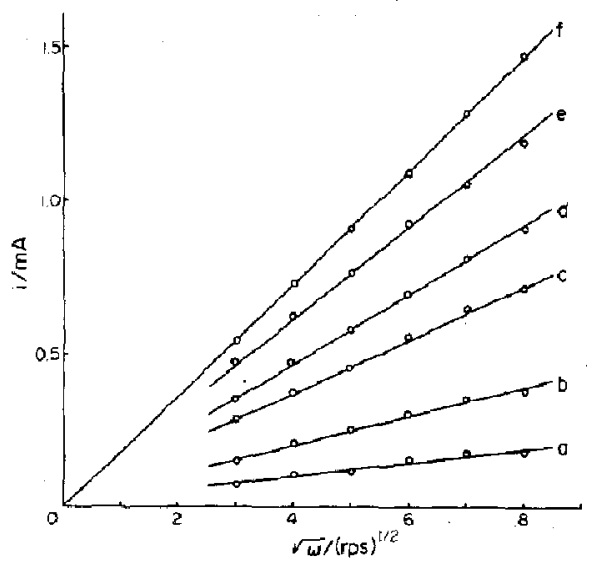

Fig. 3. Dependence of the current on the square root of the rotation speed for the oxidation of iodide to triiodide and iodine at various potentials; (a) $0.325 \mathrm{~V}$, (b) $0.35 \mathrm{~V}$, (c) $0.40 \mathrm{~V}$, (d) $0.45 \mathrm{~V}$, (e) $0.55 \mathrm{~V}$, (f) $0.70 \mathrm{~V}$ vs Ag/AgCl; $c_{1^{-}}=10 \mathrm{mM}$.

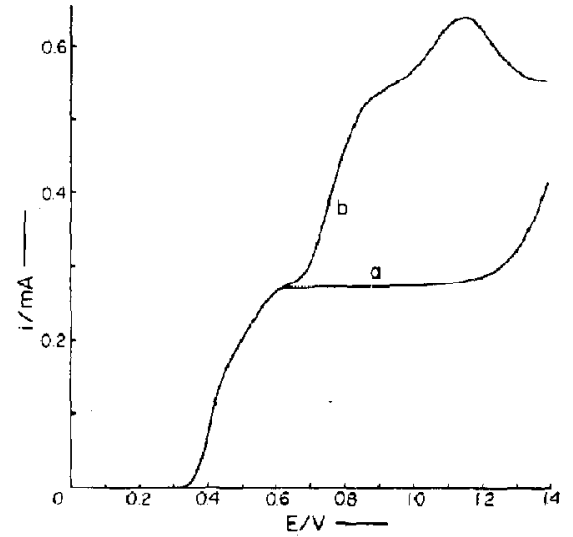

Fig. 4. Oxidation of iodide at (a) $\mathrm{pH}=4.0$ and (b) $\mathrm{pH}=8.5$. $c_{1^{-}}=3 \mathrm{mM}, \omega=9 \mathrm{rps}$.

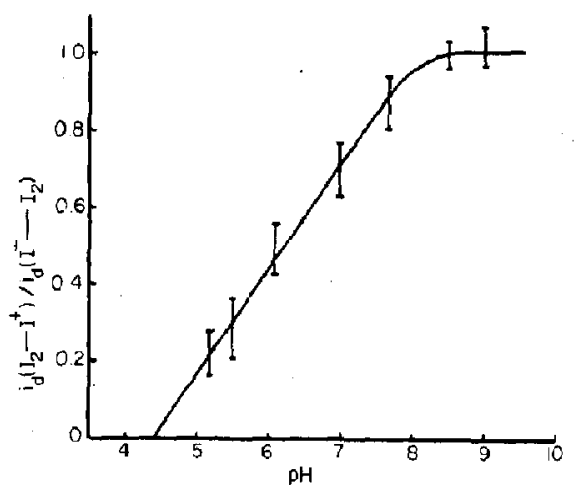

Fig. 5. Height of the iodonium wave with respect to the iodine wave as function of the $\mathrm{pH} ; c_{\mathbf{1}^{*}}=2 \mathrm{mM}, \omega=25 \mathrm{rps}$.

We measured the equilibrium potential of the couple iodine-iodonium (dipyridine) nitrate in the $\mathrm{H}$ shaped cell mentioned above, and found it to be also pH dependent (Fig. 6c). The half-wave potentials, as 


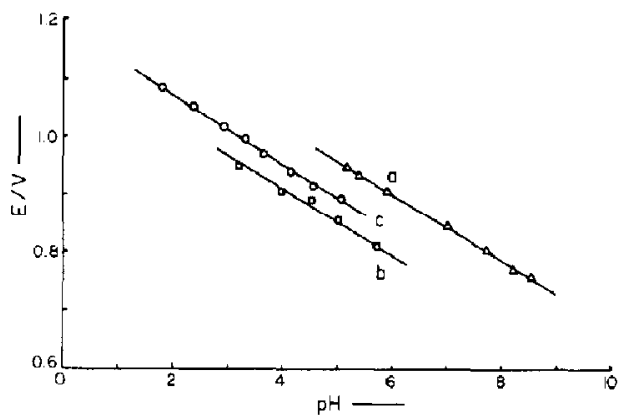

Fig. 6. $\mathrm{pH}$ dependence of the half-wave and equilibrium potentials. (a) $E_{1 / 2}(o x), c_{1^{*}}=1 \mathrm{mM}, \omega=9 \mathrm{rps}$;(b) $E_{1 / 2}$ (red), $c_{\mathrm{I}^{*}}=1 \mathrm{mM}, \omega=9 \mathrm{rps}$; (c) $E_{\mathrm{e}^{\cdot}} c_{\mathrm{l}_{\mathrm{j}}}=10 \mathrm{mM}, c_{\mathrm{I}^{+}}=100 \mathrm{mM}$.

well as the equilibrium potential, shift with a slope of $-58 \pm 2 \mathrm{mV}$ per $\mathrm{pH}$ unit. This indicates that the redox couple concerned is not the couple iodineiodonium, but the couple iodine-iodonium methoxide:

$$
\mathrm{I}_{2}+2 \mathrm{CH}_{3} \mathrm{OH} \rightleftharpoons 2 \mathrm{CH}_{3} \mathrm{OI}+2 \mathrm{H}^{+}+2 e^{-}
$$

Iodonium methoxide is not stable and decomposes quickly, probably to iodate. The peak in the voltamogram of Fig. $4 \mathrm{~b}$ is, as we assume, due to the formation of iodate. Iodates are insoluble in methanol and therefore no full wave of the iodate can develop as the electrode becomes passivated with a layer of iodate. This formation of iodate also causes the iodonium waves to sag at higher rotation speeds (Fig. 7). After a few scans,

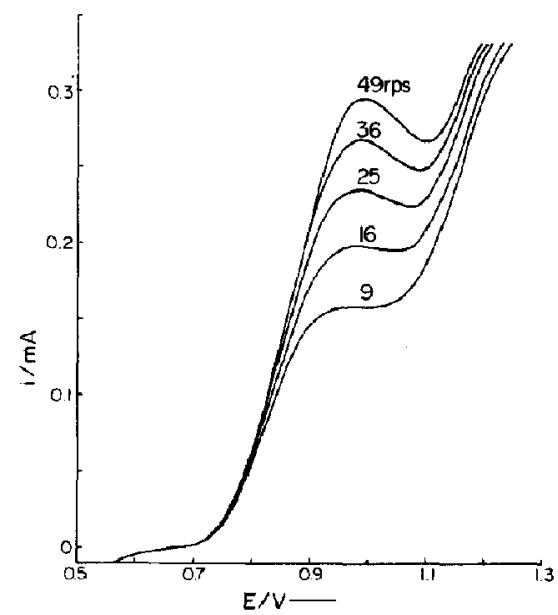

Fig. 7. The iodonium wave at different rotation speeds; only the wave $\mathrm{I}_{2} \rightarrow \mathrm{I}^{+}$is recorded. $c_{1-}=2 \mathrm{mM}, \mathrm{pH}=7.5$.

there was usually a white bloom on the electrode and, moreover, the electrode surface was pitted. Only a new polishing could restore its original shiny appearance. The iodonium waves are not very steep: we found Tafel slopes of $60 \pm 5 \mathrm{mV}$. Together with the difference in half-wave potentials for the oxidation to iodonium and for the reduction to iodine, this indicates that the waves are irreversible. As follows from the theory of the rotating disk electrode[12], the current through the electrode for a first order irreversible reaction, where the reverse reaction may be neglected, is given by

$$
\frac{\pi r^{2} n F}{i}=\frac{1}{k^{\prime} c^{m}}+\frac{1}{0.62 v^{-1 / \pi} D^{2 / 3} w^{1 / 2} c^{r}}
$$

where $i$ is the current at constant potential (ie at constant heterogeneous rate constant, $k^{\prime}$ ) and all other symbols have their usual significance. The last term corresponds with the convective diffusion current. A plot of $1 / i$ vs $1 / \sqrt{ } \omega$ at various potentials should give a straight line with an intercept due to the kinetic term and a slope predicted by the diffusion term (Fig. 8). Only at low potentials ( $i e$ low currents) the lines are in agreement with the theory. At larger currents the passivation of the electrode surface becomes more important and the lines tend to become horizontal.

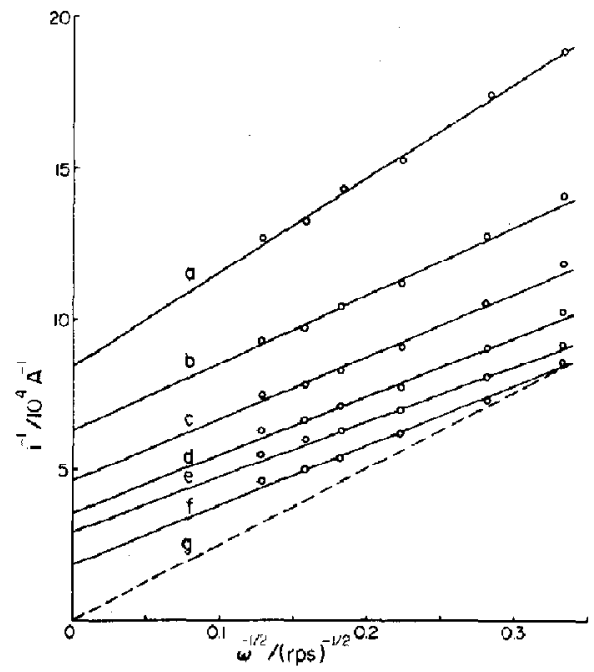

Fig. 8. $\frac{1}{i}$ os $\frac{1}{\sqrt{\omega}}$ plot for the oxidation of iodine (from iodide) to iodonium methoxide at various potentials; (a) $0.80 \mathrm{~V}$, (b) $0.825 \mathrm{~V}$, (c) $0.85 \mathrm{~V}$, (d) $0.875 \mathrm{~V}$, (e) $0.90 \mathrm{~V}$, (f) $0.925 \mathrm{~V}$ is $\mathrm{Ag} / \mathrm{AgCl}$; line (g) corresponds with the theoretical diffusion current; $c_{1^{-}}=2 \mathrm{mM}, \mathrm{pH}=7.0$.

We have also performed some titrations, the results of which are in agreement with the voltammetric experiments (Fig. 9). Successively, solutions of $0.25 \mathrm{M}$ iodide, triiodide, iodine, iodonium chloride and iodonium (dipyridine) nitrate were titrated with a $0.5 \mathrm{M}$ sodium methoxide solution. Repetition of the titrations with sodium hydroxide gave the same results. Sodium iodide is stable and does not react with the base solution; therefore, the titration of a sodium iodide solution does not differ from a titration of pure methanol. Sodium triiodide shows a very slight bend at half neutralization; iodine too shows a very slight bend at half neutralization, but a sharper bend at full neutralization: iodine first reacts with the base to form triiodide and iodonium methoxide:

$$
2 \mathrm{I}_{2}+O^{-}=\mathrm{IOR}+\mathrm{I}_{3}^{-}
$$




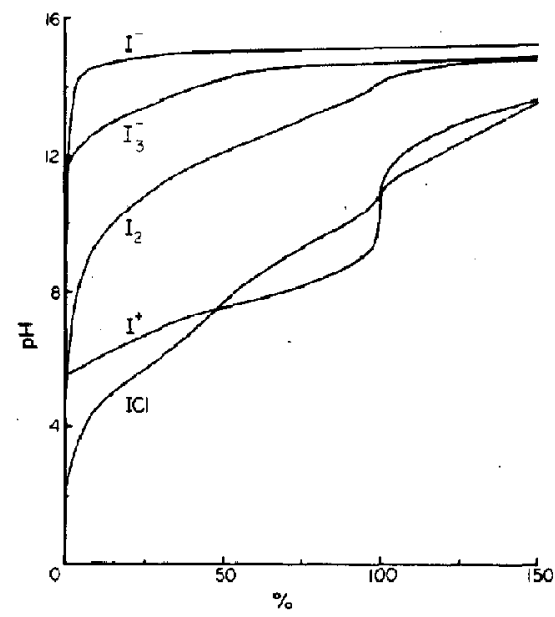

Fig. 9. Titration curves for various iodine species.

whereafter the triiodide reacts in a second step:

$$
\mathrm{I}_{3}^{-}+O \mathrm{R}^{-}=\mathrm{IOR}+2 \mathrm{I}^{-}
$$

Iodonium chloride reacts in a similar way, but in this case probably iodonium dichloride is formed:

$$
\begin{aligned}
2 \mathrm{ICl}+\mathrm{OR}^{-} & =\mathrm{ICl}_{2}^{-}+\mathrm{IO} \mathrm{R} \\
\mathrm{ICl}_{2}^{-}+\mathrm{OR}^{-} & =\mathrm{IOR}+2 \mathrm{Cl}^{-}
\end{aligned}
$$

It is clear, that iodonium dipyridine nitrate (where the pyridine serves to stabilize the iodonium ion) is simply titrated as

$$
\mathrm{I}^{+}+O \mathrm{R}^{-}=\mathrm{IOR} \text {. }
$$

The titration curves depend on the ability of the various iodine species to deliver iodonium.

In Fig. 10, a potential - pH diagram is drawn for the iodine species in methanol. As iodonium methoxide is not stable, it should not appear in the diagram. We used the equilibrium potentials of the iodineiodonium dipyridine nitrate couple and the standard redox potentials of the couple iodide-triiodide and the couple triiodide-iodine in the diagram. When the concentrations of the individual iodine species differ from $1 \mathrm{M}$, the equilibrium potentials shift according to (8) and (9).

Acknowledgement-The skilful assistance of mr. W. H. Voogt is gratefully acknowledged.

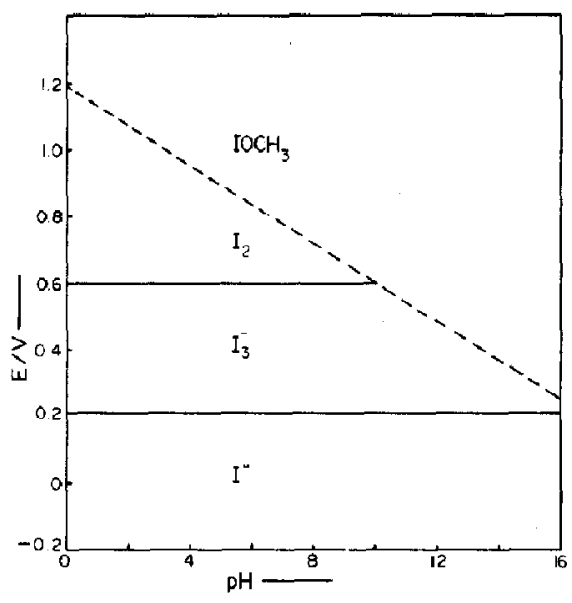

Fig. 10. Potential-pH diagram for the various iodine species.

\section{REFERENCES}

1. P. G. Desideri, L. Lepri and D. Heimler, Encyclopedia of Electrochemistry of the Elements (Edited by A. J. Bard), Vol. I. Maroel Dekker, New York (1973).

2. G. Durand and B. Trémillon, Analyt. chim. Acta 49,135 (1970); M. Mastragostino, G. Casabore and S. Valcher, J. electroanal. Chem, 44, 37 (1973).

3. V. A. Macagno and M. C. Giordano, Electrochim Acta 14, 335 (1969).

4. J. E. Barbaskeva, Yu. M. Poparov and P. D. Lukovtsev, Elektrokhimiya 8, 1275 (197.2).

5. M. C. Giordano, J. C. Bazán and A. J. Arvfa, Electrochim. Acta 11, 1553 (1966).

A. J. Arvia, M. C. Giordano and J. J. Podestá, ibid. 14, 389 (1969).

6. B. Lopez, T. Iwasita and M. C. Giordano, J. electroanal. Chem. 47, 409 (1973).

7. J. M. Nigretto and M. Jozefowicz, Electrachim. Acta 19, 809 (1974).

8. R. Guidelli and G. Piccardi, Electrochim. Acta 12, 1085 (1967).

9. B. Trémillon, La Chimie en Solvants Non-Aqueux. Presses Universitaires de France, Paris (1971).

10. S. Bruckenstein, J. electrochem. Soc. 122, 1215 (1975)

11. D. E. Smith, Electroanalytical Chemistry (Edited by A. J. Bard), Vol. I. Marcel Dekker, New York (1966).

12. A. C. Riddiford, Advances in Electrochemistry and Electrochemical Engineering (Edited by P. Delahay), Vol. IV. Interscience, New York (1966). 